\title{
Erratum to: Classifying Risk Development and Predicting Parolee Recidivism with Growth Mixture Models
}

\author{
Andy Hochstetler ${ }^{1} \cdot$ David J. Peters ${ }^{1} \cdot$ Matt DeLisi $^{1}$
}

Published online: 16 February 2016

(C) Southern Criminal Justice Association 2016

\section{Erratum to: Am J Crim Just (2016)}

DOI: 10.1007/s12103-015-9320-8

Due to an error in typesetting, the spacing in Table 2 is incorrect. The first column on the table is the LSI number. The second is titled Mean 4 LSIs, and the third is titled Mean 3 LSIs. The original version has been corrected.

The online version of the original article can be found at http://dx.doi.org/10.1007/s12103-015-9320-8.

Andy Hochstetler

hochstet@iastate.edu

1 Department of Sociology, Iowa State University, 203 East Hall, Ames, IA 50011-1071, USA 